\title{
Et varsko mot varmebehandlet soya
}

\author{
Naturlig soyaprotein senker totalkolesterol i blod. Men soyaprotein \\ som er behandlet med høy temperatur øker kolesterolmengden i blod. \\ Dette kan øke risikoen for hjerte- og karsykdom.
}

Soyaprotein som er behandlet med høy temperatur inngår bl.a. i soyamelk og andre soyabaserte drikkevarer, produkter med lang holdbarhetstid. Slike varer brukes av store mengder konsumenter. Lars Henrik Høies forskning viser at soyaprotein reduserer mengden LDL-kolesterol og totalkolesterol i blodet, men effekten er motsatt for soyaprotein behandlet ved svært høy temperatur. Resulta-

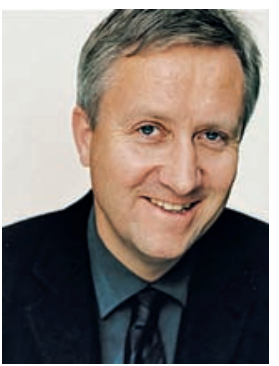

Lars Henrik Høie. Foto Universitetet i Oslo tene bygger på seks kliniske studier, der soyaprotein ble gitt som kosttilskudd til pasienter med type 2-diabetes eller hyperkolesterolemi. - At varmebehandlet soyaprotein kan øke nivåene av totalkolesterol og LDL-kolesterol i blodet med $20 \%$ i løpet av åtte uker, var overraskende. Studier med et nyutviklet soyaprotein som ikke var varmebehandlet underbygde resultatene: Disse studiene viste en signifikant reduksjon av LDL-kolesterol og totalkolesterol allerede etter få ukers bruk. Melkeproteiner som er behandlet med høy varme gir samme effekt. Alle proteinholdige drikkevarer som er aseptisk behandlet ser dermed ut til å øke disse risikofaktorene for hjerte- og karsykdom, sier Høie.

Han mener det er svært viktig å være klar over denne effekten av varmebehandlet soya. Helsemyndigheter i USA og England har godtatt at daglig inntak av produkter som inneholder minst $25 \mathrm{~g}$ soyaprotein kan sies å redusere risiko for hjerte- og karsykdom. Dette gjelder ikke for varmebehandlet protein.

\section{Anne Forus}

anneforus@hotmail.com

Tidsskriftet

\section{Ordforklaring}

De kliniske studiene: Studiene ble utført ved universitetssykehus i de nordiske landene og Tyskland. Studiene pågikk i 4-8 uker, med 25-145 pasienter i hver studie. Den store økningen i LDL- og totalkolesterol ble dokumentert allerede etter fire uker. Forskjellen mellom varmebehandlet og naturlig protein skyldes antakelig at høy temperatur denaturerer soyaproteinet og gir peptider med andre egenskaper når det går gjennom fordøyelsessystemet.

\section{Doktorgradsinformasjon}

Høie forsvarte avhandlingen Cholesterol lowering effects of soy protein, and how denatured protein may increase the risk for cardiovascular disease for ph.d.-graden ved Universitetet i Oslo 20.1. 2011.

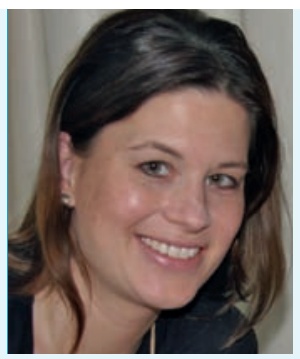

Tone Svilaas Foto privat

\section{Utsuging av blodproppen gir langt bedre gjennomblødning i hjerte- muskelen og bedre klinisk tilstand enn konvensjonell ballongdilatasjon ved ST-elevasjonsmyokardinfarkt.}

Rask gjenopprettelse av gjennomblødningen i kransarterien er essensielt i behandlingen av ST-elevasjonsmyokardinfarkt (STEMI). Siden 1980-årene har primær perkutan koronar intervensjon (PCI) vært standardbehandling. Et hult kateter føres inn via lysken og opp til hjertet, og en ballong $i$ enden av dette blåser proppen ut til siden i blodåren (ballongdilatasjon). Senere er det blitt vanlig også å legge inn stent etter utblokkingen for at blodåren skal kunne holde seg åpen lenger. En ny metode - trombeaspirasjon - er å suge ut blodproppen gjennom kateteret og deretter legge inn stent.

Tone Svilaas har i sin avhandling gjort en undersøkelse på 1080 pasienter med akutt ST-elevasjonsmyokardinfarkt. De fikk enten konvensjonell ballongdilatasjon eller trombeaspirasjon - begge etterfulgt av stent og trombolytisk behandling.

- Aspirasjonsmetoden ga en overlegen bedring av gjennomblødningen i hjertemuskelen og bedret tilstand både etter én måned og etter ett år. Etter ett år var den kardiale dødeligheten 3,6\% i denne gruppen, mot $6,7 \%$ i gruppen som fikk konvensjonell behandling. Bedre effekt kan skyldes at når blodproppen suges ut først, er det mindre av den som kan løsne og forsvinne videre i åren. Med denne metoden kan man også analysere blodproppmaterialet, noe som kan gi viktige opplysninger om faktorer som påvirker danning av blodpropp og som også skulle kunne brukes i den videre behandlingen av et hjerteinfarkt, sier Svilaas.

I Groningen i Nederland, der hun disputerte, brukes aspirasjonsmetoden nå som standardbehandling.

\section{Eline Feiring}

eline.feiring@legeforeningen.no

Tidsskriftet

\section{Ordforklaringer}

Trombeaspirasjon: Utsuging av blodpropp.

PCI: Primær perkutan koronar intervensjon (utblokking)

STEMI: Hjerteinfarkt som rammer hele muskelveggen (transmuralt) og som gir karakteristiske ST-forandringer i elektrokardiogrammet.

\section{Doktorgradsinformasjon}

Tone Svilaas disputerte for ph.d.-graden ved universitetet i Groningen, Nederland 13.12. 2010 med avhandlingen Primary percutaneous coronary intervention and the role of thrombus aspiration. 